\title{
MECHANISMS IN ENDOCRINOLOGY \\ Autoimmune thyroid disease: old and new players
}

\author{
Grigoris Effraimidis and Wilmar M Wiersinga \\ Department of Endocrinology and Metabolism, Academic Medical Center, Room F5-169, University of Amsterdam,
} Meibergdreef 9, Amsterdam 1105AZ, The Netherlands

\author{
Correspondence \\ should be addressed \\ to W M Wiersinga \\ Email \\ w.m.wiersinga@amc.uva.nl
}

\begin{abstract}
The last 10 years have seen some progress in understanding the etiology of autoimmune thyroid disease (AITD). The female preponderance can now be explained - at least in part - by fetal microchimerism and X-chromosome inactivation. The number of identified susceptibility genes for AITD is increasing (among others now including TSHR, TG, HLA, CTLA4, PTPN22, CD40, FCRL3, IL2RA, and FOXP3), but these genes together probably do not explain more than about $10 \%$ of the heritability of AITD. As twin studies indicate that genes contribute for $70 \%$ of AITD, it follows that there must be many more loci, each of them contributing a little. While the genetic studies have clarified why various autoimmune diseases so often cluster in the same patient, the molecular mechanism of action of these genetic polymorphisms (frequently located in introns) has hardly been explained. Polymorphisms in AITD susceptibility genes may become helpful in clinical practice, e.g. in assessing risk of recurrent Graves' hyperthyroidism (GH) after a course of antithyroid drugs. Moderate alcohol intake decreases the risk on overt GH and overt Hashimoto's hypothyroidism. Current smokers - as well known - are at increased risk for Graves' disease, but - surprisingly - at diminished risk for Hashimoto's thyroiditis. Low selenium and low vitamin D levels might increase the risk of developing AITD, but data are still inconclusive. Current options for preventive interventions in subjects at risk to develop AITD are very limited.

\section{Introduction}

Autoimmune thyroid disease (AITD) is a multifactorial or so-called 'complex' disease in which autoimmunity against thyroid antigens develops against a particular genetic background facilitated by exposure to environmental factors (Fig. 1). AITD encompasses a spectrum of conditions ranging from Hashimoto's hypothyroidism $(\mathrm{HH})$ at one end to Graves' hyperthyroidism $(\mathrm{GH})$ at the other end. Thyroid peroxidase (TPO) and thyroglobulin (Tg) are the major autoantigens in Hashimoto's disease, but TPO-Ab and Tg-Ab occur also in $\sim 70 \%$ of patients with Graves' disease. The thyroid-stimulating hormone receptor (TSHR) is the major autoantigen in Graves' disease, but TSHR antibodies occur also in some patients with Hashimoto's disease. Graves' and Hashimoto's

Invited Author's profile

W M Wiersinga MD, PhD is Professor Emeritus of Endocrinology at the University of Amsterdam in The Netherlands. He was Chair of the Division of Endocrinology and Metabolism in the Academic Medical Center, Amsterdam from 1995 to 2008. He is past president of the European Thyroid Association and served on the Executive Committee of the European Society of Endocrinology. His research interests are autoimmune thyroid diseases in particular Graves' ophthalmopathy (he was one of the founders of EUGOGO), nonthyroidal illness syndrome, and amiodarone.

(c) 2014 European Society of Endocrinology Printed in Great Britain
Published by Bioscientifica Ltd. 


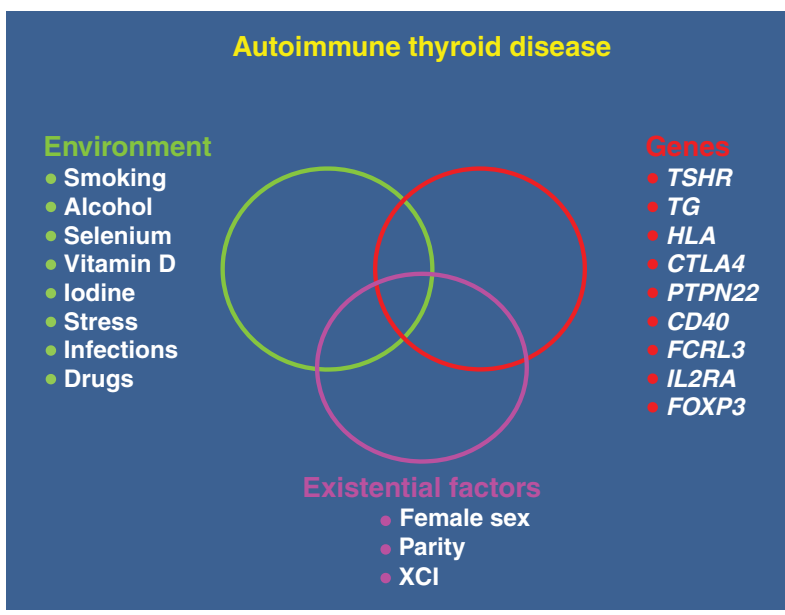

\section{Figure 1}

Venn diagram illustrating the multifactorial etiology of autoimmune thyroid disease.

diseases share some but not all known AITD susceptibility genes. Similarly, for environmental exposures: one environmental factor may constitute a risk for both Graves' and Hashimoto's diseases or for just one of them, but another factor can be risky for Graves' disease but protective for Hashimoto's disease. In this review, we focus on what has been learnt in the last 10 years on the etiology of AITD: Is the predilection for female gender better understood? Have new susceptibility genes been detected? And has progress been made with respect to environmental insults? Have there been new players in this field, or have remaining issues with old players been clarified? Finally, if individuals are at risk to develop AITD in view of their family history of AITD, is there anything they can do in terms of AITD prevention?

\section{Existential factors}

There is a strong female preponderance among AITD patients, with a female:male ratio ranging from 5:1 to 10:1. The biologic explanation of the gender difference has puzzled physicians for a long time, and only recently there have been some clues.

\section{Parity}

During pregnancy the serum concentrations of thyroid antibodies decrease, related to generation of maternal regulatory T-cells $\left(\mathrm{T}_{\text {reg }}\right.$ ) early in pregnancy that maintain a state of tolerance to fetal alloantigens in order to prevent rejection of the fetus (1). After delivery, there is a rebound with a transient rise in thyroid antibodies. The post partum period carries a risk for the onset of Graves' disease although the risk might have been overestimated (2), and post partum thyroiditis is often the forerunner of permanent autoimmune hypothyroidism (3). In the prospective Amsterdam AITD cohort study, the prevalence of pregnancy and post partum was higher in those developing overt hyper-/hypothyroidism than in those remaining euthyroid (4). Parity as a risk factor for AITD has received much attention in relation to fetal microchimerism. There is transfer of fetal cells into the maternal circulation, already in the first trimester. Fetal microchimerism results when fetal cells persist in maternal tissues, and it is hypothesized that maternal immune responses against foreign fetal antigens might trigger autoimmune diseases. Fetal microchimerism has indeed been found in blood and thyroid tissue from women with Hashimoto's or Graves' disease (5). Using parity as a surrogate for increasing fetal cell exposure, one would expect the higher the number of pregnancies is, the higher the frequency and/or concentration of thyroid antibodies will be. However, the results have been conflicting. Several population-based studies have observed that there was no association between parity and TPO-Ab any longer after adjustment for maternal age and other important confounders $(6,7,8)$. Other equally large studies do report associations that remain significant after adjustments, using higher cutoff values for TPO-Ab positivity. Odds ratio (OR) for AITD (defined as TPO-Ab $>200 \mathrm{kU} / \mathrm{l}$ ) was increased in women with $\geq 1$ pregnancy compared with nulliparous women (OR, 1.8; 95\% CI, 1.0-3.3) (9). In another study, the trend analysis for risk of $\mathrm{TPO}-\mathrm{Ab}$ with increasing parity was significant only at TPO-Ab $>500 \mathrm{kU} / \mathrm{l}$ and not at lower levels (10). In a populationbased Danish cohort, women with children, compared with childless women, were at a relative risk of 1.11 (1.08-1.14) for autoimmune diseases with female predominance; associations with parity were found for Hashimoto's thyroiditis (1.11; 1.00-1.24) and Graves' disease $(1.19 ; 1.14-1.24)$ (11). Taken together, the data suggest that parity is somehow involved in the development of AITD but only to a modest extent, and parity explains only partially the female preponderance of AITD. Fetal microchimerism might contribute, but its effect is rather limited. The potential role of microchimerism in developing thyroid autoimmunity is further supported by twin studies: both female and male twins of opposite-sex pairs, as opposed to monozygotic pairs, have an increased frequency of thyroid antibodies (12). 


\section{X-chromosome inactivation}

In female mammalian cells, one of the two X chromosomes is inactivated in early embryonic life. Female tissues are thus mosaics of two cell lines, one with the paternal and the other with the maternal $\mathrm{X}$ chromosome as the active $X$. Usually, there is a random 50:50 ratio of the two cell lines. A skewed X-chromosome inactivation (XCI) is defined - arbitrarily - as inactivation of the same $\mathrm{X}$ chromosome in $\geq 80 \%$ of cells (13). The consequence could be that self-antigens on one $\mathrm{X}$ chromosome are not expressed at sufficiently high levels in the thymus or at peripheral sites involved in tolerance induction. Loss of immunological tolerance to X-linked antigens might induce autoimmunity. Several studies have shown that skewed XCI is associated with an increased risk of developing AITD. A meta-analysis confirmed significant skewing of XCI in women with Graves' disease (OR, 2.54; 95\% CI, 1.58-4.10) and Hashimoto's disease (OR, 2.40; 95\% CI, 1.10-5.26) (14). The epigenetic phenomenon of skewed XCI may, in part, explain the strong female preponderance in AITD.

\section{Genetic factors}

Susceptibility genes for AITD can be divided into thyroidspecific genes and immunoregulatory genes. Identified thyroid-specific genes are TSHR and TG, but not TPO. One explanation for this discrepancy could be that TSHR and $T G$ (but not TPO) are polymorphic. Single-nucleotide polymorphisms (SNPs) in TSHR have been specifically associated with Graves' disease and not with autoimmune hypothyroidism in a Caucasian population $(15,16)$, although more recently associations with Hashimoto's thyroiditis as well are described in a Chinese Han population (17). The functional consequences of these intronic SNPs are not entirely clear. They could give rise to RNA splice variants, increasing the level of potential autoantigenic TSHR-A subunits (16). Alternatively, SNP carriers may have fewer thymic TSHR mRNA transcripts, which may decrease central tolerance to TSHR (18). Multiple SNPs in $T G$ have been associated with both Graves' and Hashimoto's diseases, but SNPs are located in exons in Caucasians and in introns in Japanese $(19,20)$. The immunoregulatory genes HLA class II, CTLA4, and PTPN22 were already recognized as risk factors in the 20th century by case-control studies. They are all involved in the immunological synapse, in which antigenic peptides complexed in HLA molecules are presented by antigenpresenting cells (not only macrophages and dendritic cells, but also B-cells) to $\mathrm{T}$-cell receptors on T-cells. Polymorphisms in these genes are not specific for AITD, as they also confer susceptibility for other autoimmune diseases. A single amino acid variation in the peptidebinding cleft of HLA-DR, resulting in an arginine residue at position 74 of the $\beta$-chain, is strongly associated with Graves' disease. An interaction with the SNP in exon 33 of $T G$ has been described, suggesting that HLA-DR $\beta$-Arg 74 presents the disease-associated TG SNP alleles more efficiently to T-cells: an example of gene-gene interaction resulting in synergism $(19,21)$. Many more susceptibility loci have been detected since 2005 by genome-wide association studies (22). Among these are HLA class I molecules, which present endogenous antigens to the immune system (including those derived from viruses which are possible environmental triggers for AITD). HLA-C demonstrated a much stronger association with Graves' disease in Caucasians than HLA-DRB1, DQA1, and DQB1, with HLA-C ${ }^{*} 07$ predisposing and HLA-C ${ }^{*} 03$ and HLA-C ${ }^{*} 16$ being protective; HLA-B was found to be associated independent of HLA-C (23). In Han Chinese, HLA-B was a risk factor for Hashimoto's disease (24). CD40, a co-stimulator of antigen-presenting cells, is also expressed on nonimmune cells such as thyrocytes. An SNP in the Kozak sequence of $C D 40$ is associated with Graves' disease in Caucasians and Koreans, but not in Taiwanese $(19,25)$. It increases the expression of CD4O mRNA and protein in the thyroid. A polymorphism in the Fc receptorlike 3 gene (FCRL3) is predisposing for several autoimmune diseases including Graves' disease, in both Caucasians and Chinese Han population $(26,27)$. The association with FCRL5 is secondary to the effect of FCRL 3 (26). The gene encodes for a member of the immunoglobulin receptor superfamily, expressed on B-cells. FCRL3 polymorphisms may be involved in the pathogenesis of Graves' disease by excessive inhibition of B-cell receptor signaling and the impairment of suppressing function of $\mathrm{T}_{\text {reg }}$ (27). Two other genes, IL2RA and FOXP3, encode markers for $\mathrm{T}_{\text {reg-cells and are involved in immunological }}$ tolerance. CD25 is a marker for the interleukin 2 (IL2) receptor $\alpha$ chain present predominantly on CD25+T-cells, and it is a susceptibility locus for Graves' disease (28). FOXP3 encodes a forkhead/winged helix transcription factor expressed in naturally arising $\mathrm{T}_{\text {reg, }}$ committing naïve T-cells to become $\mathrm{T}_{\text {reg }}$. Mutations in FOXP3 result in the fatal immunodysregulation, polyendocrinopathy, enteropathy, X-linked (IPEX) syndrome. Polymorphisms in FOXP3 have been associated with AITD in Caucasians (especially with Graves' disease developing below the age of 30 years) but not in Japanese $(29,30)$. The location of 
FOXP3 on the $\mathrm{X}$ chromosome might contribute to the female preponderance of AITD. Mutations in autoimmune regulator $(A I R E)$ gene, expressed in thymic medullary epithelial cells, result in failure to present self-antigens correctly in the thymus leading to a loss of self-tolerance and thereby to autoimmune polyglandular syndrome type 1 . However, AIRE mutations are rarely present in adult AITD patients (in about $0.3-0.6 \%$ of patients with Graves' disease and autoimmune hypothyroidism); thus AIRE is not considered as a susceptibility gene contributing to the more common autoimmune endocrinopathies $(31,32)$. Genome-wide association studies continue to detect additional genes and loci conferring risk for AITD (21).

What can be learnt from this multitude of genetic studies? First, it has provided a deeper insight into the molecular mechanisms involved in the immunopathogenesis of AITD. But at the same time it must be acknowledged that the mechanism of action of many susceptibility loci is incompletely understood (why are so many SNPs located in noncoding parts of the gene?), that the mechanisms are much more complex than previously thought, and that we have hardly started studying genegene and gene-environment interactions. Secondly, we have a better understanding as to why autoimmune diseases are associated with each other, and so often cluster in the same patient. Thirdly, the OR of each locus for AITD is rather low in the order of 1.5-2.0, with slightly higher OR of 2.0-4.0 for HLA. Combining the effects of four HLA loci and five non-HLA loci, they accounted for only $9.3 \%$ of heritability of Graves' disease in a Chinese study (33). Twin studies have convincingly demonstrated that genetic factors contribute about 70\% to the development of AITD, leaving only 30\% for environmental factors (34). The data strongly suggest that there must be many more still undetected susceptibility genes, each variant contributing just a little to the development of AITD. Fourthly, application of knowledge about susceptibility genes is slowly entering clinical practice. Some polymorphisms have predictive value for whether or not $\mathrm{GH}$ will recur after a course of antithyroid drugs $(35,36)$. One may expect that susceptibility genes are going to play a substantial role in personalized medicine.

\section{Environmental factors: new players}

\section{Smoking}

Smoking is a well-established risk factor for Graves' disease. The OR for $\mathrm{GH}$ is 3.30 (95\% CI, 2.09-5.22) in current smokers when compared with never smokers.
The OR for Graves' ophthalmopathy is even higher: OR 4.40 (95\% CI, 2.88-6.73) in ever smokers vs never smokers. The risk disappears a few years after cessation of smoking: the OR for Graves' disease in ex-smokers vs never smokers is 1.41 (95\% CI, 0.77-2.58), not significant any longer. These figures were already published in a 2002 metaanalysis, which at that time also concluded that smoking was not associated with hypothyroidism (37). In the last few years, however, convincing evidence has been obtained that current smoking protects against (autoimmune) hypothyroidism. Although smoking is an old player in the relation between environmental exposures and autoimmunity, the discovery of its protective effect allows the label 'new player' (Fig. 2). The evidence is derived from large cross-sectional population-based surveys and from prospective observational studies. In NHANES III, the prevalence of TSH $>4.5 \mathrm{mU} / 1$ is lower in smokers than in nonsmokers (2.6 vs $5.5 \%$, relative risk (RR) 0.5 with 95\% CI, 0.4-0.6), in a dose-dependent manner (38). In the Norwegian HUNT study, the ORs (current smokers vs never smokers) for subclinical and overt hypothyroidism are 0.54 (95\% CI, 0.45-0.66) and 0.60 (95\% CI, 0.38-0.95) respectively in women; the corresponding figures in men are 0.37 (95\% CI, 0.26-0.52) and 0.51 (95\% CI, 0.15-1.73). ORs for former smokers were not significant (39). In this study, the cause of hypothyroidism was not specified but most probably it was Hashimoto's thyroiditis because subjects with previously known and treated thyroid disease had been excluded. Subsequent studies indeed demonstrate a protective effect

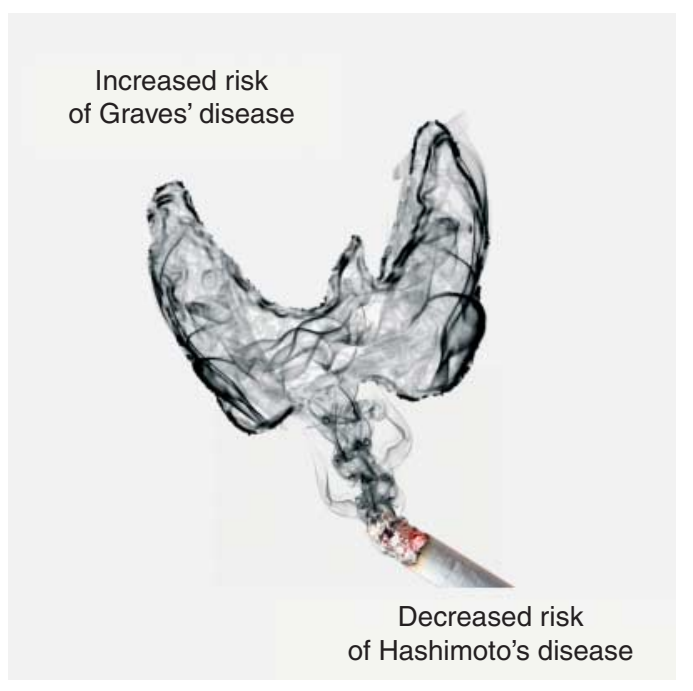

Figure 2

Current smoking is a risk factor for Graves' disease but protective for Hashimoto's disease. 
against Hashimoto's disease. In NHANES III, TPO-Abs were present in $11 \%$ of smokers vs $18 \%$ in nonsmokers (OR 0.57 ; 95\% CI, 0.48-0.67), with a dose-response relationship (38). In the Amsterdam AITD cohort study at baseline, 25\% of subjects, with TPO-Ab at baseline, smoked vs $38 \%$ of subjects without TPO-Ab (OR 0.69; 95\% CI, 0.48-0.99) (40). In Denmark, smoking was also negatively associated with $\mathrm{Tg}-\mathrm{Ab}$ and to a lesser degree with TPO-Ab (41). Follow-up of subjects in the Amsterdam AITD cohort, who had no thyroid antibodies at baseline, revealed that cessation of smoking increased the risk of de novo development of TPO$\mathrm{Ab}$ and $\mathrm{Tg}-\mathrm{Ab}$ (42); there was a significant trend toward more quitters in subjects who progressed to autoimmune hypothyroidism than in subjects who remained euthyroid (4). In the prospective DanThyr study, patients with newly diagnosed autoimmune hypothyroidism had more often quitted smoking in the last 2 years than controls (16.4 vs $3.4 \%$ ) (43). The increased risk after smoking cessation, however, was transient: ORs $<1,1-2$, and 3-10 years after quitting are 7.36 (95\% CI, 2.27-23.90), 6.34 (95\% CI, 2.5915.3 ), and 0.75 (95\% CI, 0.30-1.87) respectively. Finally, using Danish nationwide registers, mothers who smoke during pregnancy have a subsequent decreased risk of developing hypothyroidism (hazard ratio (HR), 0.75; 95\% CI, 0.70-0.81) and an increased risk of hyperthyroidism (HR, 1.38; 95\% CI, 1.27-1.49) (44). Thus, current smoking diminishes the risk of developing TPO-Ab/Tg-Ab and autoimmune hypothyroidism in a dose-dependent manner, but the protective effect disappears a few years after quitting smoking. The contrast with the increased risk of smoking for GH is striking, but poorly understood. One may hypothesize involvement of nicotine, which reduces the severity of experimental autoimmune encephalomyelitis by a shift from pathogenic Th1 and Th17 responses to protective Th2 responses. Anatabine - a tobacco alkaloid with a structure similar to nicotine - reduces the incidence and severity of experimental autoimmune thyroiditis (45).

\section{Alcohol}

Case-control studies nested in the Amsterdam AITD cohort did not observe an association between alcohol consumption (defined as $>10$ units/week) and de novo occurrence of TPO-Ab, but the prevalence of alcohol consumption was lower in subjects developing autoimmune hypothyroidism during the 5-year follow-up than in those remaining euthyroid (6.7 vs $23.7 \%$ ) (46). A population-based case-control study in Denmark also provided evidence for a protective role of alcohol consumption for the development of autoimmune hypothyroidism. ORs were as follows: 1.98 (95\% CI, 1.21-3.33) for 0 alcoholic units/week, 1.00 for 1-10 units/week (reference), 0.41 (95\% CI, 0.20-0.83) for 11-20 units/week, and 0.90 (95\% CI, 0.41-2.00) for $\geq 21$ units/week (47). Abstainers are 2.17 times more likely to develop autoimmune hypothyroidism than nonabstainers ( $\geq 1$ unit/week). Remarkably, moderate alcohol consumption is likewise associated with a considerable reduction in the risk of $\mathrm{GH}$. ORs were 1.73 (95\% CI, 1.17-2.56) for 0 units/week, 1.00 for 1-2 units/week (reference), 0.56 (95\% CI, 0.39-0.79) for 3-10 units/week, 0.37 (95\% CI, 0.21-0.65) for 11-20 units/week, and 0.22 (95\% CI, $0.08-0.60)$ for $\geq 21$ units/week (48). No interaction was found with the type of alcohol (wine vs beer), smoking habits, gender, or iodine intake. Two previous casecontrol studies reported similar protective effects of alcohol for GH with ORs of 0.3 (95\% CI, 0.2-0.7) and 0.4 (95\% CI, 0.2-0.8) $(49,50)$, although not confirmed in another study (51). The observed associations likely indicate a cause-and-effect relationship in view of the strength and the consistency of the associations and the presence of a dose-response effect. Moreover, alcohol is known to protect against other autoimmune diseases such as rheumatoid arthritis and type 1 diabetes. The most likely explanation for the protective effect of alcohol on AITD is that moderate alcohol consumption has a beneficial impact on the immune system compared with alcohol abuse or abstinence (52). However, the effect of alcohol on the immune system is complex, and how alcohol suppresses autoimmunity remains incompletely understood. Alcohol has also a direct toxic effect on the thyroid gland, which, however, is difficult to reconcile with its protective effect against hypothyroidism.

\section{Selenium}

Glutathione peroxidases and thioredoxin reductases are selenoproteins involved in regulation of the redox state and protection from oxidative damage. The thyroid gland contains more selenium per gram of tissue than any other organ. The enzyme GPx3 protects thyrocytes from oxidative stress generated by the action of $\mathrm{H}_{2} \mathrm{O}_{2}$. Low selenium levels have been associated with poor immune function $(53,54)$. It has thus been hypothesized that even mild nutritional selenium deficiency may promote the initiation or progression of thyroid autoimmunity. To test the hypothesis that selenium supplementation decreases the serum concentration of TPO-Ab, six randomized clinical trials have been performed $(55,56,57,58,59,60)$. 
The results are equivocal: selenium compared with placebo decreased TPO-Ab in three studies but not in the other three studies. The discrepant results could not be explained from the use of sodium selenite or selenomethionine, sample size, baseline serum concentrations of Se (ranging from 69 to $75 \mu \mathrm{g} / \mathrm{l}$ ), and TPO-Ab (ranging from 172 to $1875 \mathrm{kU} / \mathrm{l})$, nor be explained from the concomitant use of levothyroxine ( $\left(\mathrm{L}-\mathrm{T}_{4}\right)(60)$. At present, it cannot be excluded that selenium supplementation will decrease TPO-Ab specifically in regions with iodine deficiency (which increases the amount of oxidative stress to the thyroid gland), or when given for a period longer than 6 months. Selenium supplementation has proven to prevent deterioration of mild Graves' ophthalmopathy (61) and the post partum surge of TPO-Ab and thyroid dysfunction (62). These randomized clinical trials were performed in countries with marginally low selenium blood levels, and it is not known if equally favorable results are seen in selenium-replete areas. The selenium dose used so far is $200 \mu \mathrm{g}$ daily. In the Dutch trial, it increased plasma Se concentrations from $73 \mu \mathrm{g} / \mathrm{l}$ at baseline to $96 \mu \mathrm{g} / \mathrm{l}$ at 3 months and $95 \mu \mathrm{g} / \mathrm{l}$ at 6 months; obviously, a plateau had been reached within 3 months, which was also true for Selenoprotein P (60). Supplementation of selenium to people who already have adequate Se intake with their food might increase their risk of developing type 2 diabetes, particularly when baseline plasma Se concentrations are $\geq 122 \mu \mathrm{g} / \mathrm{l}$ (63). There may be health benefits and no extra risk for people with baseline (Se) $<122 \mu \mathrm{g} / \mathrm{l}$ by raising their selenium status, perhaps to $130-150 \mu \mathrm{g} / \mathrm{l}$, which is associated with minimal mortality (63). Finally, it might be possible that individual requirements for selenium differ because of polymorphisms in selenoprotein genes. A Cochrane systematic review concludes that data at present do not allow confident decision making about the use of selenium supplementation for Hashimoto's thyroiditis (64).

\section{Vitamin D}

Many immunocompetent cells (monocytes, macrophages, dendritic cells, T-lymphocytes, and B-lymphocytes) express the vitamin D-activating enzyme CYP27B1 and the vitamin $\mathrm{D}$ receptor (VDR). The active hormone $1,25(\mathrm{OH})_{2} \mathrm{D}$ (derived from the systemic circulation or from local conversion of $25(\mathrm{OH}) \mathrm{D})$ binds to VDR and modulates both the innate and adaptive immune systems $(65,66)$. Low vitamin D levels have been identified as a risk factor for various autoimmune diseases such as type 1 diabetes, rheumatoid arthritis, multiple sclerosis, and
Crohn's disease. The situation with respect to AITD is less clear. The prospective Amsterdam AITD cohort was used for a nested case-control study: cases and controls had baseline normal TSH and no thyroid antibodies, but during the 5-year follow-up, cases did develop de novo $\mathrm{TPO}-\mathrm{Ab}$ whereas controls remained without antibodies. Controls were carefully matched to cases not only for the duration of follow-up, but also for conditions known to affect vitamin D levels such as age, BMI, smoking status, estrogen use, and month of blood sampling (not for sex because the Amsterdam AITD cohort consists of women only). Serum $25(\mathrm{OH}) \mathrm{D}$ and $1,25(\mathrm{OH})_{2} \mathrm{D}$ concentrations were not different between cases and controls, neither at baseline nor at the time of seroconversion (67). The remaining studies are all cross-sectional in nature. Some of them do find lower vitamin $\mathrm{D}$ levels in subjects with TPO-Ab $(68,69,70)$, while others do not $(71,72)$. Interpretation of their study results is difficult because controls were not always matched to cases for the many other conditions affecting vitamin D levels. For example, in one study, the inverse relationship between vitamin D status and thyroid antibodies was lost after correcting for sex and age (72). However, a recent study from Korea in 6685 subjects undergoing routine health checkups tried to avoid confounding factors and observed lower $25(\mathrm{OH}) \mathrm{D}$ levels in women with TPO-Ab than in control women without TPO-Ab (22.0 vs $23.5 \mathrm{ng} / \mathrm{ml} ; P=0.03)$; there was no difference in men (73). The prevalence of TPO-Ab in women with vitamin D deficiency, insufficiency, and sufficiency was $21.2,15.5$, and $12.6 \%$ respectively $(P=0.027)$. ORs adjusted for age, BMI, serum calcium, smoking, menopause, and season were (relative to an OR of 1.00 for vitamin D sufficiency) 1.95 for vitamin D deficiency and 1.31 for vitamin D insufficiency. Whether vitamin D supplementation will prevent AITD has not been studied. Finally, polymorphisms in the VDR gene are associated with AITD: whereas ApaI or FokI carry no risk, the BsmI and TaqI polymorphisms decrease the risk for AITD (OR, 0.80; 95\% CI, 0.71-0.91 and OR, 0.85; 95\% CI, $0.76-0.96$ respectively) (74).

\section{Environmental factors: old players}

\section{lodine}

Thyroid antibodies and autoimmune hypothyroidism are more common in iodine-replete areas than in iodinedeficient areas. Further elegant proof of this has recently been obtained from population-based studies in Denmark. Prevalence figures before and after mandatory iodization 
of salt were 14.3 and $23.8 \%$ for TPO-Ab, and 13.7 and $19.9 \%$ for $\mathrm{Tg}-\mathrm{Ab}$ respectively; ORs were 1.80 (TPO-Ab) and 1.49 (Tg-Ab). The increase in frequency was most pronounced in young females and at low concentrations of antibodies (75). The incidence rate of hypothyroidism at baseline was 38.3/100 000 per year, increasing to $47.2 / 100000$ per year 5-7 years after iodine fortification of salt (RR, 1.23; 95\% CI, 1.07-1.42) (76). Voluntary iodine prophylaxis in a small rural community in Italy also resulted in an increased frequency of thyroid antibodies (12.6 vs $19.5 \%$ ) and hypothyroidism (2.8 vs $5.0 \%) 15$ years later (77). Implementation of iodine prophylaxis in this study contributed to thyroid autoimmunity by unmasking a cryptic epitope on $\mathrm{Tg}$ (78).

\section{Stress}

It has been known for a long time that stress could be a provocative factor for $\mathrm{GH}$, although the evidence is circumstantial (79). Annual assessment of stressful life events and daily hassles in the prospective Amsterdam AITD cohort demonstrated no association between stress exposure and de novo occurrence of TPO-Ab or autoimmune hypothyroidism (80). Thus, in contrast to

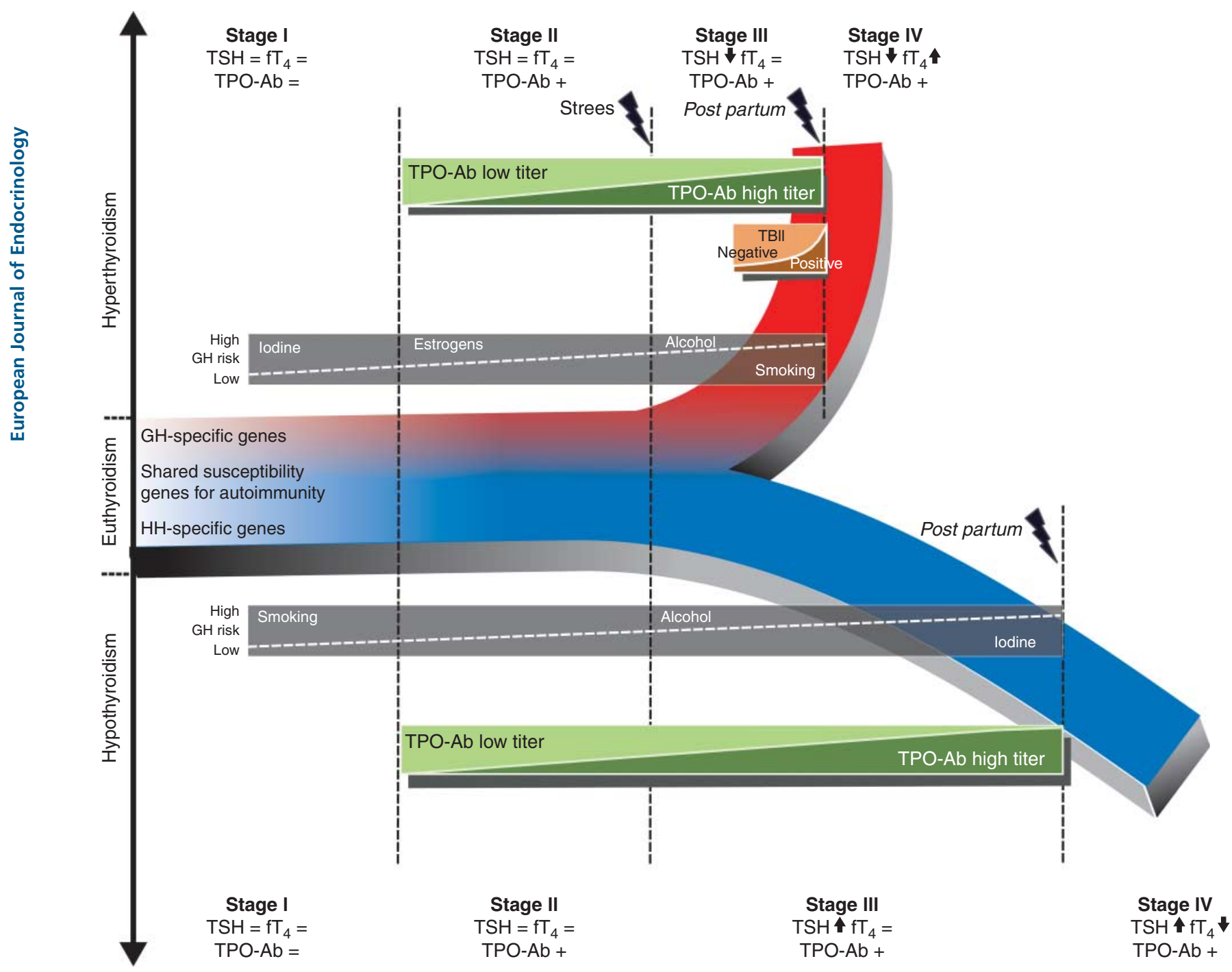

Figure 3

Natural history of autoimmune thyroid disease. GH, Graves' hyperthyroidism; HH, Hashimoto's hypothyroidism. 
Graves' disease, stress is apparently not involved in Hashimoto's thyroiditis.

\section{Infections}

Infection with Yersinia enterocolitica (YE) has long been implicated in the pathogenesis of AITD, because IgG from Graves' patients inhibit binding of TSH to outer membranes of YE, and IgG from patients with YE infection inhibit binding of TSH to thyroid membranes. Biological plausibility of an association has recently been enhanced by cross-reactivity between YE outer membrane proteins (YOP) and epitopes of TSHR antibodies (81, 82, 83). Clinical evidence about the role of YE infection remains controversial. In twin pairs discordant for Graves' disease, subjects with Graves' disease had an increased OR of YE infection (IgA, 1.84; 95\% CI, 0.99-3.45 and IgG, 1.90; 95\% CI, 1.02-3.55) (84). The Amsterdam AITD cohort, the only prospective study in this area, however, did not find any evidence of an association between YOP IgA or IgG status and de novo occurrence of thyroid antibodies or development of overt autoimmune hyper/ hypothyroidism (85). Hepatitis $\mathrm{C}$ virus (HCV) might be 'the only infectious agent that is clearly associated with an increased risk for autoimmune thyroiditis' (86). HCV can infect human thyrocytes resulting in production of proinflammatory cytokines, which may enhance the autoimmune response (87). Indeed, thyroid antibodies are more frequent in children with untreated $\mathrm{HCV}$ infection than in controls (88). Enteroviruses have been detected in thyroid tissue of subjects with Hashimoto's thyroiditis (89). It is hypothesized that gut microbiota may trigger Hashimoto's thyroiditis (90). One can even speculate that the profound changes in gut microbiota induced by smoking cessation (91) are related to the loss of the protective effect of current smoking for Hashimoto's disease.

\section{Drugs}

Treatment with interferon $\alpha$ frequently results in Hashimoto's thyroiditis (less often in Graves' disease), especially in women with pre-existent TPO-Ab (92). It may induce autoimmune hypothyroidism by direct toxic effects on thyrocytes as well as provocation of destructive bystander immune responses (93). Treatment with alemtuzumab (anti-CD52 MAB) or highly active anti-retroviral therapy causes depletion of lymphocytes; in the recovery phase, when CD4+T-cells rise, there is a risk of the emergence of autoreactive clones. Thus, both drugs could induce the immune reconstitution syndrome, expressed as $\mathrm{GH}$ and less frequently as hypothyroidism (94).

\section{Natural history of AITD and prevention}

Figure 3 schematically depicts the natural history of AITD. In stage I, all thyroid function tests are normal and thyroid antibodies are absent in serum. But at this stage in subjects at risk to develop AITD (like those with a family history of AITD), evidence of immune activation can already be found from a characteristic pattern of serum proteins related to growth/connective tissue abnormalities and migration/accumulation abnormalities of macrophages and dendritic cells (95). In stage II, thyroid antibodies become detectable in serum. The concentration of thyroid antibodies gradually increases, TSH but not $\mathrm{FT}_{4}$ becomes abnormal and we are entering stage III: subclinical thyroid dysfunction. The duration of subclinical hyperthyroidism until overt GH occurs (stage IV) is much shorter than the duration of subclinical hypothyroidism until overt $\mathrm{HH}$ develops (stage IV) (4, 96). A number of prospective population-based studies have identified serum TSH and thyroid antibodies as predictors of future hypothyroidism and hyperthyroidism $(97,98,99,100)$. The quantitative risk of developing overt AITD can be estimated by the Thyroid Events Amsterdam (THEA) score based on TSH, TPO-Ab, and family history of AITD (97). The question arises whether a person at risk can take preventive action in order to diminish the risk. As shown in Table 1, the options are very limited. To stop smoking will steer the natural history away from Graves' disease toward Hashimoto's disease. Moderate alcohol intake would make sense, but there is insufficient evidence to justify preventive medication with selenium or vitamin D. Moreover, to refrain from pregnancy and to avoid stress are not very helpful recommendations either.

Table 1 Possible preventive interventions to decrease the risk of developing autoimmune thyroid disease.

\begin{tabular}{|c|c|c|c|}
\hline $\begin{array}{l}\text { Preventive } \\
\text { intervention }\end{array}$ & $\begin{array}{l}\text { Risk of } \\
\text { TPO-Ab }\end{array}$ & $\begin{array}{l}\text { Risk of } \\
\text { Hashimoto's } \\
\text { hypo- } \\
\text { thyroidism }\end{array}$ & $\begin{array}{l}\text { Risk of } \\
\text { Graves' } \\
\text { hyper- } \\
\text { thyroidism }\end{array}$ \\
\hline Stop smoking & Increase & Increase & Decrease \\
\hline Use alcohol & No change & Decrease & Decrease \\
\hline Use selenium & $?$ & $?$ & $?$ \\
\hline Use vitamin D & $?$ & $?$ & $?$ \\
\hline Avoid pregnancy & Decrease & Decrease & Decrease \\
\hline Avoid stress & No change & No change & Decrease \\
\hline
\end{tabular}




\section{Declaration of interest}

The authors declare that there is no conflict of interest that could be perceived as prejudicing the impartiality of the review.

\section{Funding}

This review did not receive any specific grant from any funding agency in the public, commercial or not-for-profit sector.

\section{References}

1 Weetman AP. Immunity, thyroid function and pregnancy: molecular mechanisms. Nature Reviews. Endocrinology 20106 311-318. (doi:10.1038/nrendo.2010.46)

2 Rodondi M, Pirali B, Lodigiani S, Bray S, Chytiris S, Balzano S, Magri F \& Chiovato L. The post partum period and the onset of Graves' disease: an overestimated risk factor. European Journal of Endocrinology 2008 159 161-165. (doi:10.1530/EJE-08-0236)

3 Stagnaro-Green A, Schwartz A, Gismondi R, Tinelli A, Mangieri T \& Negro R. High rate of persistent hypothyroidism in a large-scale prospective study of postpartum thyroiditis in southern Italy. Journal of Clinical Endocrinology and Metabolism 201196 652-657. (doi:10.1210/ jc.2010-1980)

4 Effraimidis G, Strieder TG, Tijssen JG \& Wiersinga WM. Natural history of the transition from euthyroidism to overt autoimmune hypo- or hyperthyroidism: a prospective study. European Journal of Endocrinology 2011164 107-113. (doi:10.1530/EJE-10-0785)

5 Lepez T, Vandewoestyne M, Hussain S, van Nieuwerburgh F, Poppe K, Velkeniers B, Kaufman J-M \& Deforce D. Fetal microchimeric cells in blood of women with an autoimmune thyroid disease. PLOS ONE 2011 6 e29646. (doi:10.1371/journal.pone.0029646)

6 Walsh JP, Bremner AP, Bulsara MK, O'Leary P, Leedman PJ, Feddema P $\&$ Michelangeli V. Parity and the risk of autoimmune thyroid disease: a community-based study. Journal of Clinical Endocrinology and Metabolism 200590 5309-5312. (doi:10.1210/jc.2005-0771)

7 Bulow Pedersen I, Laurberg P, Knudsen N, Jorgensen T, Perrild H, Ovesen L \& Rasmussen LB. Lack of association between thyroid antibodies and parity in a population study argues against microchimerism as a trigger of thyroid autoimmunity. European Journal of Endocrinology 2006154 39-45. (doi:10.1530/eje.1.02070)

8 Sgarbi JA, Kasamatsu TS, Matsumura LK \& Maciel RM. Parity is not related to autoimmune thyroid disease in a population-based study of Japanese Brazilians. Thyroid 201020 1151-1156. (doi:10.1089/ thy.2009.0424)

9 Friedrich N, Schwarz S, Thonack J, John U, Wallaschofski H \& Volzke H. Association between parity and autoimmune thyroiditis in a general female population. Autoimmunity 200841 174-180. (doi:10.1080/08916930701777629)

10 Greer LG, Casey BM, Halvorson LM, Spong CY, McIntire DD \& Cunningham G. Antithyroid antibodies and parity: further evidence for microchimerism in autoimmune thyroid disease. American Journal of Obstetrics and Gynecology 2011205 471.e1-471.e4. (doi:10.1016/j.ajog.2011.06.060)

11 Jorgensen KT, Pedersen BV, Nielsen NM, Jacobsen S \& Frisch M. Childbirths and risk of female predominant and other autoimmmune diseases in a population-based Danish cohort. Journal of Autoimmunity 201238 J81-J87. (doi:10.1016/j.jaut.2011.06.004)

12 Brix TH, Hansen PS, Kyvik KO \& Hegedus L. Aggregation of thyroid antibodies in twins from opposite-sex pairs suggest that microchimerism may play a role in the early stages of thyroid autoimmunity. Journal of Clinical Endocrinology and Metabolism 200994 4439-4443. (doi:10.1210/jc.2009-0813)
13 Brix TH, Knudsen GPS, Kristiansen M, Kyvik KO, Orstavik KH \& Hegedus L. High frequency of skewed X-chromosome inactivation in females with autoimmune thyroid disease: a possible explanation for the female predisposition to thyroid autoimmunity. Journal of Clinical Endocrinology and Metabolism 200590 5949-5953. (doi:10.1210/jc. 2005-1366)

14 Simmonds MJ, Kavvoura FK, Brand OJ, Newby PR, Jackson LE, Hargreaves CE, Franklyn JA \& Gough SC. Skewed X chromosome inactivation and female preponderance in autoimmune thyroid disease: an association study and meta-analysis. Journal of Clinical Endocrinology and Metabolism 201499 E127-E131. (doi:10.1210/jc. 2013-2667)

15 Dechairo BM, Zabaneh D, Collins J, Brand O, Dawson GJ, Green AP, Mackay I, Franklyn JA, Connell JM, Wass JA et al. Association of the TSHR gene with Graves' disease: the first disease specific locus. European Journal of Human Genetics 200513 1223-1230. (doi:10.1038/ sj.ejhg.5201485)

16 Brand OJ, Barrett JC, Simmonds MJ, Newby PR, McCabe CJ, Bruce CK, Kysela B, Carr-Smith JD, Brix T, Hunt PJ et al. Association of the thyroid stimulating hormone receptor gene (TSHR) with Graves' disease. Human Molecular Genetics 200918 1704-1713. (doi:10.1093/ hmg/ddp087)

17 Liu L, Wu HQ, Wang Q, Zhu YF, Zhang W, Guan LJ \& Zhang JA. Association between thyroid stimulating hormone receptor intron polymorphisms and autoimmune thyroid disease in a Chinese Han population. Endocrine Journal 201259 717-723. (doi:10.1507/endocrj. EJ12-0024)

18 Colobran R, Armengol MP, Fauer R, Gartner M, Tykocinski LO, Lucas A, Ruiz M, Juan M, Kyewski B \& Pujol-Borrell R. Association of an SNP with intrathymic transcription of TSHR and Graves' disease: a role for defective thymic tolerance. Human Molecular Genetics 201120 3415-3423. (doi:10.1093/hmg/ddr247)

19 Jacobson EM \& Tomer Y. The CD4O, CTLA-4, thyroglobulin, TSH receptor, and PTPN22 gene quintet and its contribution to thyroid autoimmunity: back to the future. Journal of Autoimmunity $2007 \mathbf{2 8}$ 85-98. (doi:10.1016/j.jaut.2007.02.006)

20 Ban Y, Tozaki T, Taniyama M, Skrabanek L, Nakano Y, Ban Y \& Hirano T. Multiple SNPs in intron 41 of thyroglobulin gene are associated with autoimmune thyroid disease in the Japanese population. PLOS ONE 20127 e37501. (doi:10.1371/journal.pone. 0037501)

21 Hodge SE, Ban Y, Strug LJ, Greenberg DA, Davies TF, Concepcion ES, Villanueva R \& Tomer Y. Possible interaction between HLA-DR $\beta 1$ and thyroglobulin variants in Graves' disease. Thyroid 200614 351-356. (doi:10.1089/thy.2006.16.351)

22 Simmonds MJ. GWAS in autoimmune thyroid disease: redefining our understanding of pathogenesis. Nature Reviews. Endocrinology 20139 277-287. (doi:10.1038/nrendo.2013.56)

23 Simmonds MJ, Howson JM, Heward JM, Carr-Smith J, Franklyn JA, Todd JA \& Gough SC. A novel and major association of HLA-C in Graves' disease that eclipses the classical HLA-DRB1 effect. Human Molecular Genetics 200716 2149-2153. (doi:10.1093/hmg/ddm165)

24 Huang CY, Chang TY, Chu CC, Lo FS, Ting WH, Lin CH, Wu YL, Chu SY, Chang SC, Chen WF et al. The HLA-B gene and Hashimoto disease in Han children: a case-control and family-based study. Tissue Antigens 201280 431-436. (doi:10.1111/tan.12003)

25 Hsiao JY, Tien KJ, Hsiao CT \& Hsieh MC. A C/T polymorphism in CD40 gene is not associated with susceptibility and phenotype of Graves' disease in Taiwanese. Endocrine Journal 200855 477-484. (doi:10.1507/endocrj.K07E-071)

26 Simmonds MJ, Brand OJ, Barrett JC, Newby PR, Franklyn JA \& Gough SC. Association of Fc receptor-like 5 (FCRL5) with Graves' disease is secondary to the effect of FRCL3. Clinical Endocrinology 2010 73 654-660. (doi:10.1111/j.1365-2265.2010.03843.x)

27 Zhao S-X, Liu W, Zhan M, Song Z-Y, Yang S-Y, Xue L-Q, Pan C-M, Gu Z-H, Liu B-L, Wang H-N et al. A refined study of FRCL genes from a 
genome-wide association study for Graves' disease. PLoS ONE 20138 e57758. (doi:10.1371/journal.pone.0057758)

28 Brand OJ, Lowe CE, Heward JM, Franklyn JA, Cooper JD, Todd JA \& Gough SC. Association of the interleukin-2 receptor $\alpha$ (IL-2R $\alpha) / C D 25$ gene region with Graves' disease using a multilocus test and tag SNPs. Clinical Endocrinology 2007 66 508-512. (doi:10.1111/j.1365-2665.2007.02762.x)

29 Owen CJ, Eden JA, Jennings CE, Wilson V, Cheetham TD \& Pearce SH. Genetic association studies of the FOXP3 gene in Graves' disease and autoimmune Addison's disease in the United Kingdom population. Journal of Molecular Endocrinology 200637 97-104. (doi:10.1677/jme.1. 02072)

30 Ban Y, Tozaki T, Tobe T, Ban Y, Jacobson EM, Concepcion ES \& Tomer Y. The regulatory $\mathrm{T}$ cell gene FOXP3 and genetic susceptibility to thyroid autoimmunity: an association analysis in Caucasian and Japanese cohorts. Journal of Autoimmunity 200728 201-207. (doi:10.1016/j.jaut.2007.02.016)

31 Nithiyananthan R, Heward JM, Allahabadia A, Barnett AH, Franklyn JA \& Gough SC. A heterozygous deletion of the autoimmune regulator (AIRE1) gene, autoimmune thyroid disease, and type 1 diabetes: no evidence for association. Journal of Clinical Endocrinology and Metabolism 200085 1320-1322.

32 Meyer G, Donner H, Herwig J, Bohles H, Usadel KH \& Badenhoop K. Screening for an AIRE-1 mutation in patients with Addison's disease, type 1 diabetes, Graves' disease and Hashimoto's thyroiditis as well as APECED syndrome. Clinical Endocrinology 200154 335-338. (doi:10.1046/j.1365-2265.2001.01230.x)

33 Chu X, Pan CM, Zhao SX, Liang J, Gao GQ, Zhang XM, Yuan GY, Li CG, Xue LQ, Shen $M$ et al. A genome-wide association study identifies two new risk loci for Graves' disease. Nature Genetics 201143 897-901. (doi:10.1038/ng.898)

34 Brix TH \& Hegedus L. Twin studies as a model for exploring the aetiology of autoimmune thyroid disease. Clinical Endocrinology 2012 76 457-464. (doi:10.1111/j.1365-2265.2011.04318.x)

35 Inoue N, Watanabe M, Yamada H, Takemura K, Hayashi F, Yamakawa N, Akahane M, Shimizuishi Y, Hidaka Y \& Iwatani Y. Associations between autoimmune thyroid disease prognosis and functional polymorphisms of susceptibility genes, CTLA4, PTPN22, CD40, FCRL3, and ZFAT, previously revealed in genome-wide association studies. Journal of Clinical Immunology 201232 1243-1252. (doi:10.1007/s10875-012-9721-0)

36 Wang PW, Chen IY, Juo SHH, His E, Liu RT \& Hsieh CJ. Genotype and phenotype predictors of relapse of Graves' disease after antithyroid drug withdrawal. European Thyroid Journal 20121 251-258. (doi:10.1159/000342021)

37 Vestergaard P. Smoking and thyroid disorders - a meta-analysis. European Journal of Endocrinology 2002146 153-161. (doi:10.1530/ eje.0.1460153)

38 Belin RM, Astor BC, Powe NR \& Ladenson PW. Smoke exposure is associated with a lower prevalence of serum thyroid autoantibodies and thyrotropin concentration elevation and a higher prevalence of mild thyrotropin concentration suppression in the third National Health and Nutrition Examination Survey (NHANES III). Journal of Clinical Endocrinology and Metabolism 200489 6077-6086. (doi:10.1210/jc.2004-0431)

39 Asvold BO, Bjoro T, Nilsen TI \& Vatten LJ. Tobacco smoking and thyroid function: a population-based study. Archives of Internal Medicine 2007167 1428-1432. (doi:10.1001/archinte.167.13.1428)

40 Strieder TG, Prummel MF, Tijssen JG, Endert E \& Wiersinga WM. Risk factors for and prevalence of thyroid disorders in a cross-sectional study among healthy female relatives of patients with autoimmune thyroid disease. Clinical Endocrinology 200359 396-401. (doi:10.1046/ j.1365-2265.2003.01862.x)

41 Bulow Pedersen I, Laurberg P, Knudsen N, Jorgensen T, Perrild H, Ovesen L \& Rasmussen LB. Smoking is negatively associated with the presence of thyroglobulin autoantibody and to a lesser degree with thyroid peroxidase autoantibody in serum: a population study.
European Journal of Endocrinology 2008158 367-373. (doi:10.1530/ EJE-07-0595)

42 Effraimidis G, Tijssen JG \& Wiersinga WM. Discontinuation of smoking increases the risk for developing thyroid peroxidase antibodies and/or thyroglobulin antibodies: a prospective study. Journal of Clinical Endocrinology and Metabolism 200994 1324-1328. (doi:10.1210/jc.2008-1548)

43 Carle A, Bulow Pedersen I, Knudsen N, Perrild H, Ovesen L, Rasmussen LB, Jorgensen T \& Laurberg P. Smoking cessation is followed by a sharp but transient rise in the incidence of overt autoimmune hypothyroidism - a population-based, case-control study. Clinical Endocrinology 201277 764-772. (doi:10.1111/ j.1365-2265.2012.04455.x)

44 Andersen SL, Olsen J, Wu CS \& Laurberg P. Smoking reduces the risk of hypothyroidism and increases the risk of hyperthyroidism: evidence from 450842 mothers giving birth in Denmark. Clinical Endocrinology 201480 307-314. (doi:10.1111/cen.12279)

45 Caturegli P, De Remigis A, Ferlito M, Landek-Salgado, Iwama S, Tzou S-C \& Ladenson PW. Anatabine ameliorates experimental autoimmune thyroiditis. Endocrinology 2012153 4580-4587. (doi:10.1210/en.2012-1452)

46 Effraimidis G, Tijssen JG \& Wiersinga WM. Alcohol consumption as a risk factor for autoimmune thyroid disease: a prospective study. European Thyroid Journal 20121 99-104. (doi:10.1159/000338920)

47 Carle A, Bulow Pedersen I, Knudsen N, Perrild H, Ovesen L, Rasmussen LB, Jorgensen T \& Laurberg P. Moderate alcohol consumption may protect against overt autoimmune hypothyroidism: a population-based case-control study. European Journal of Endocrinology 2012167 483-490. (doi:10.1530/EJE-12-0356)

48 Carle A, Bulow Pedersen I, Knudsen N, Perrild H, Ovesen L, Rasmussen LB, Jorgensen T \& Laurberg P. Graves' hyperthyroidism and moderate alcohol consumption: evidence for disease prevention. Clinical Endocrinology 201379 111-119. (doi:10.1111/cen.12106)

49 Yoshiuchi K, Kumano H, Nomura S, Yoshimura H, Ito K, Kanaji Y, Ohashi Y, Kuboki T \& Suematsu H. Stressful life events and smoking were associated with Graves' disease, but not in men. Psychosomatic Medicine 199860 182-185.

50 Winsa B, Adami HO, Bergstrom R, Gamstedt A, Dahlberg PA, Adamson U, Jansson R \& Karlsson A. Stressful life events and Graves disease. Lancet 1991338 1475-1479. (doi:10.1016/01406736(91)92298-G)

51 Holm IA, Manson JE, Michels KB, Alexander EK, Willett WC \& Utiger RD. Smoking and other lifestyle factors and the risk of Graves' hyperthyroidism. Archives of Internal Medicine 2005165 1606-1611. (doi:10.1001/archinte.165.14.1606)

52 Romeo J, Warnberg J, Nova E, Diaz LE, Gomez-Martinez S \& Marcos A. Moderate alcohol consumption and the immune system: a review. British Journal of Nutrition 200798 (Suppl 1) S111-S115.

53 Duntas LH. Selenium and the thyroid: a close-knit association. Journal of Clinical Endocrinology and Metabolism 201095 5180-5188. (doi:10.1210/jc.2010-0191)

54 Schomburg L. Selenium, selenoproteins and the thyroid gland. Nature Reviews. Endocrinology 20118 160-171. (doi:10.1038/nrendo. 2011.174)

55 Gartner R, Gasnier BC, Dietrich JW, Krebs B \& Angstwurm MW. Selenium supplementation in patients with autoimmune thyroiditis decreases thyroid peroxidase antibodies concentrations. Journal of Clinical Endocrinology and Metabolism 200287 1687-1691. (doi:10.1210/jcem.87.4.8421)

56 Duntas LH, Mantzou E \& Koutras DA. Effect of a six-month treatment with selenomethionine in patients with autoimmune thyroiditis. European Journal of Endocrinology 2003148 389-393. (doi:10.1530/eje. $0.1480389)$

57 Turker O, Kumanlioglu K, Karapolat I \& Dogan I. Selenium treatment in autoimmune thyroiditis: 9-month follow-up with variable doses. Journal of Endocrinology 2006190 151-156. (doi:10.1677/joe.1.06661) 
58 Karanikas G, Schuetz M, Kontur S, Duan H, Kommata S, Schoen R, Antoni A, Kletter K, Dudczak R \& Willheim M. No immunological benefit of selenium in consecutive patients with autoimmune thyroiditis. Thyroid 200818 7-12. (doi:10.1089/thy.2007.0127)

59 Nacamulli D, Mian C, Petricca D, Lazzarotto F, Barollo S, Pozza D, Masiero S, Faggian D, Plebani M, Girelli ME et al. Influence of physiological dietary selenium supplementation on the natural course of autoimmune thyroiditis. Clinical Endocrinology 201073 535-539. (doi:10.1111/j.1365-2265.2009.03750.x)

60 Eskes SA, Endert E, Fliers E, Birnie E, Hollenbach B, Schomburg L, Kohrle J \& Wiersinga WM. Selenite supplementation in euthyroid subjects with thyroid peroxidase antibodies. Clinical Endocrinology 200480 444-451. (doi:10.1111/cen.12284)

61 Marcocci M, Kahaly GJ, Krassas GE, Bartalena L, Prummel M, Stahl M, Altea MA, Nardi M, Pitz S, Boboridis K et al. Selenium and the course of mild Graves' orbitopathy. New England Journal of Medicine 2011364 1920-1931. (doi:10.1056/NEJMoa1012985)

62 Negro R, Greco G, Mangieri T, Pezzarossa A, Dazzi D \& Hassan H. The influence of selenium supplementation on postpartum thyroid status in pregnant women with thyroid peroxidase autoantibodies. Journal of Clinical Endocrinology and Metabolism 200792 1263-1268. (doi:10.1210/jc.2006-1821)

63 Rayman MP. Selenium and human health. Lancet 2012379 1256-1268. (doi:10.1016/S0140-6736(11)61452-9)

64 Van Zuuren EJ, Albusta AY, Fedorowicz Z, Carter B \& Pijl H. Selenium supplementation for Hashimoto's thyroiditis. Cochrane Database of Systematic Reviews 20136 CD010223. (doi:10.1002/14651858. CD010223.pub2\#sthash.6FfFTJ1W.dpuf)

65 Van Belle TL, Gysemans C \& Mathieu C. Vitamin D in autoimmune, infectious and allergic diseases: a vital player? Best Practice \& Research. Clinical Endocrinology \& Metabolism 201125 617-632. (doi:10.1016/ j.beem.2011.04.009)

66 Hewison M. An update on vitamin D and human immunity. Clinical Endocrinology 201276 315-325. (doi:10.1111/j.1365-2265.2011. 04261.x)

67 Effraimidis G, Badenhoop K, Tijssen JG \& Wiersinga WM. Vitamin D deficiency is not associated with early stages of thyroid autoimmunity. European Journal of Endocrinology 2012167 43-48. (doi:10.1530/ EJE-12-0048)

68 Kivity S, Agmon-Levin N, Zisappi M, Shapira Y, Nagy EV, Danko K, Szekanecz Z, Langevitz P \& Shoenfeld Y. Vitamin D and autoimmune thyroid diseases. Cellular \& Molecular Immunology 20118 243-247. (doi:10.1038/cmi.2010.73)

69 Tamer G, Arik S, Tamer I \& Coksert D. Relative vitamin D insufficiency in Hashimoto's thyroiditis. Thyroid 201121 891-896. (doi:10.1089/ thy.2009.0200)

70 Camurdan OM, Doger E, Bideci A, Celik N \& Cinaz P. Vitamin D status in children with Hashimoto thyroiditis. Journal of Pediatric Endocrinology and Metabolism 201225 467-470. (doi:10.1515/ jpem-2012-0021)

71 Goswami R, Marwaha RK, Gupta N, Tandon N, Sreenivas V, Tomar N, Ray D, Kanwar R \& Agarwal R. Prevalence of vitamin D deficiency and its relationship with thyroid autoimmunity in Asian Indians: a community-based survey. British Journal of Nutrition $2009 \mathbf{1 0 2}$ 382-386. (doi:10.1017/S0007114509220824)

72 Chailurkit L, Aekplakorn W \& Ongphiphadhanakul B. High vitamin D status in younger individuals is associated with low circulating thyrotropin. Thyroid 201323 25-30. (doi:10.1089/thy.2012.0001)

73 Choi YM, Kim WG, Kim TY, Bae SJ, Kim HK, Jang EK, Jeon M, Han JM, Lee $\mathrm{SH}$, Baek JH et al. Low levels of serum vitamin D3 are associated with autoimmune thyroid disease in pre-menopausal women. Thyroid 2014. In press.

74 Feng M, Li H, Chen S-F, Li W-F \& Zhang F-B. Polymorphisms in the vitamin $\mathrm{D}$ receptor gene and risk of autoimmune thyroid diseases: a meta-analysis. Endocrine 201343 318-326. (doi:10.1007/s12020012-9812-y)
75 Bulow Pedersen I, Knudsen N, Carle A, Vejbjerg P, Jorgensen T, Perrild H, Ovesen L, Rasmussen BL \& Laurberg P. A cautious iodization program bringing iodine intake to a low recommended level is associated with an increase in the prevalence of thyroid autoantibodies in the population. Clinical Endocrinology 201175 120-126. (doi:10.1111/j.1365-2265.2011.04008.x)

76 Pedersen IB, Laurberg P, Knudsen N, Jorgensen T, Perrild H, Ovesen L $\&$ Rasmussen LB. An increased incidence of overt hypothyroidism after iodine fortification of salt in Denmark: a prospective population study. Journal of Clinical Endocrinology and Metabolism 200792 3122-3127. (doi:10.1210/jc.2007-0732)

77 Aghini Lombardi F, Fiore E, Tonacchera M, Antonangeli L, Rago T, Frigeri M, Provenzale AM, Montanelli L, Grasso L, Pinchera A et al. The effect of voluntary iodine prophylaxis in a small rural community: the Pescopagano survey 15 years later. Journal of Clinical Endocrinology and Metabolism 201398 1031-1039. (doi:10.1210/jc.2012-2960)

78 Latrofa F, Fiore E, Rago T, Antonangeli L, Montanelli L, Ricci D, Provenzale MA, Scutari M, Frigeri M, Tonacchera M et al. Iodine contributes to thyroid autoimmunity in humans by unmasking a cryptic epitope on thyroglobulin. Journal of Clinical Endocrinology and Metabolism 201398 E1768-E1774. (doi:10.1210/jc.2013-2912)

79 Falgarone G, Heshmati HM, Cohen R \& Reach G. Role of emotional stress in the pathophysiology of Graves. European Journal of Endocrinology 2013168 R13-R18. (doi:10.1530/EJE-12-0539)

80 Effraimidis G, Tijssen JG, Brosschot JF \& Wiersinga WM. Involvement of stress in the pathogenesis of autoimmune thyroid disease: a prospective study. Psychoneuroendocrinology 201237 1191-1198. (doi:10.1016/j.psyneuen.2011.12.009)

81 Wang Z, Zhang Q, Lu J, Jiang F, Zhang H, Gao L \& Zhao J. Identification of outer membrane porin $\mathrm{f}$ protein of Yersinia enterocolitica recognized by antithyrotropin receptor antibodies in Graves' disease and determination of its epitope using mass spectrometry and bioinformatics tools. Journal of Clinical Endocrinology and Metabolism 201095 4012-4020. (doi:10.1210/jc.2009-2184)

82 Guarneri F, Carlotta D, Saraceno G, Trimarchi F \& Benvenga S. Bioinformatics support the possible triggering of autoimmune thyroid diseases by Yersinia enterocolitica outer membrane proteins homologous to the human thyrotropin receptor. Thyroid 201121 1283-1284. (doi:10.1089/thy.2010.0364)

83 Hargreaves CE, Grasso M, Hampe CS, Stenkova A, Atkinson S, Joshua GW, Wren BW, Buckle AM, Dunn-Walters D \& Banga P. Yersinia enterocolitica provides the link between thyroid-stimulating antibodies and their germline counterparts in Graves' disease. Journal of Immunology 2013190 5373-5381. (doi:10.4049/jimmunol. 1203412)

84 Brix TH, Hansen PS, Hegedus L \& Wenzel BE. Too early to dismiss Yersinia enterocolitica infection in the aetiology of Graves' disease: evidence from a twin case-control study. Clinical Endocrinology 2008 69 491-496. (doi:10.1111/j.1365-2265.2008.03227.x)

85 Effraimidis G, Tijssen JG, Strieder TG \& Wiersinga WM. No causal relationship between Yersinia enterocolitica infection and autoimmune thyroid disease: evidence from a prospective study. Clinical and Experimental Immunology 2011165 38-43. (doi:10.1111/j.1365-2249. 2011.04399.x)

86 Tomer Y. Interferon induced thyroiditis. Journal of Autoimmunity 2010 34 J322-J326. (doi:10.1016/j.jaut.2009.11.008)

87 Blackard J, Kong L, Huber A \& Tomer Y. Hepatitis C virus infection of a thyroid cell line: implications for pathogenesis of HCV an thyroiditis. Thyroid 201223 863-870. (doi:10.1089/thy.2012.0507)

88 Indolfi G, Stagi S, Bartolini E, Salti R, de Martino M, Azzari C \& Resti M. Thyroid function and anti-thyroid autoantibodies in untreated children with vertically acquired chronic hepatitis $C$ virus infection. Clinical Endocrinology 200868 117-121. (doi:10.1111/j.1365-2265. 2007.03009.x)

89 Hammerstad SS, Jahnsen FL, Tauriainen S, Hyoty H, Paulsen T, Norheim I \& Dahl-Jorgensen K. Inflammation and increased 
myxovirus resistance protein A expression in thyroid tissue in the early stages of Hashimoto's thyroiditis. Thyroid 201323 334-341. (doi:10.1089/thy.2012.0264)

90 Mori K, Nakagawa Y \& Ozaki H. Does the gut microbiota trigger Hashimoto's thyroiditis? Discovery Medicine 201214 321-326.

91 Biedermann L, Zeitz J, Mwinyi J, Sutter-Minder E, Rehman A, Ott SJ, Steurer-Stey C, Frei A, Frei P, Scharl M et al. Smoking cessation induces profound changes in the composition of the intestinal microbiota in humans. PLOS ONE 20138 e59260. (doi:10.1371/journal.pone. 0059260)

92 Tomer Y \& Menconi F. Interferon induced thyroiditis. Best Practice \& Research. Clinical Endocrinology \& Metabolism 200923 703-712. (doi:10.1016/j.beem.2009.07.004)

93 Akeno N, Smith EP, Stefan M, Huber AK, Zhang W, Keddache M \& Tomer Y. IFN- $\alpha$ mediates the development of autoimmunity by both direct tissue toxicity and through immune cell recruitment mechanisms. Journal of Immunology 2011186 4693-4706. (doi:10.4049/jimmunol.1002631)

94 Weetman AP. Immune reconstitution syndrome and the thyroid. Best Practice \& Research. Clinical Endocrinology \& Metabolism 200923 693-702. (doi:10.1016/j.beem.2009.07.003)

95 Beumer W, Effraimidis G, Drexhage RC, Wiersinga WM \& Drexhage HA. Changes in serum adhesion molecules, chemokines, cytokines, and tissue remodeling factors in euthyroid women without thyroid antibodies who are at risk for autoimmune thyroid disease: reaction. Journal of Clinical Endocrinology and Metabolism 201398 2460-2468. (doi:10.1210/jc.2012-4122)

96 Hutfless S, Matos P, Talor MV, Caturegli P \& Rose NR. Significance of prediagnostic thyroid antibodies in women with autoimmune thyroid disease. Journal of Clinical Endocrinology and Metabolism 201196 E1466-E1471. (doi:10.1210/jc.2011-0228)

97 Strieder TG, Tijssen JG, Wenzel BE, Endert E \& Wiersinga WM. Prediction of progression to overt hypothyroidism or hyperthyroidism in female relatives of patients with autoimmune thyroid disease using the Thyroid Events Amsterdam (THEA) score. Archives of Internal Medicine 2008168 1657-1663. (doi:10.1001/archinte.168.15.1657)

98 Walsh JP, Bremner AP, Feddema P, Leedman PJ, Brown SJ \& O'Leary P. Thyrotropin and thyroid antibodies as predictors of hypothyroidism: a 13-year, longitudinal study of a community-based cohort using current immunoassay techniques. Journal of Clinical Endocrinology and Metabolism 201095 1095-1104. (doi:10.1210/jc.2009-1977)

99 Roos A, Links TP, Jong-van den Berg LT, Gans RO, Wolffenbuttel BH \& Bakker SJ. Thyroid peroxidase antibodies, levels of thyroid stimulating hormone and development of hypothyroidism in euthyroid subjects. European Journal of Internal Medicine 201021 555-559. (doi:10.1016/ j.ejim.2010.09.001)

100 Asvold BO, Vatten LJ, Midthjell K \& Bjoro T. Serum TSH within the reference range as predictor of future hypothyroidism and hyperthyroidism: 11-yr follow-up of the HUNT study in Norway. Journal of Clinical Endocrinology and Metabolism 201297 93-99. (doi:10.1210/jc.2011-1724)

Received 18 January 2014

Revised version received 19 February 2014

Accepted 7 March 2014 